\title{
TRANSFER GEN ANTIVIRUS PADA EMBRIO UDANG WNDU, Penaeus monodon DALAM BERBAGAI KONSENTRASI DEOXYRIBO NUCLEIC ACID
}

\author{
Andi Parenrengi, Andi Tenriulo, Syarifuddin Tonnek, dan Samuel Lante \\ Balai Riset Perikanan Budidaya Air Payau \\ JI. Makmur Dg. Sitakka No. 129, Maros 90512, Sulawesi Selatan \\ E-mail: litkanta@indosat.net.id
}

(Naskah diterima: 29 Juli 2011; Disetujui publikasi: 28 Oktober 2011)

\begin{abstract}
ABSTRAK
Teknologi transgenesis khususnya rekayasa genetik untuk menghasilkan udang windu resisten penyakit merupakan salah satu strategi yang dapat dilakukan dalam upaya pemecahan masalah penyakit yang menimpa budidaya udang windu. Teknologi transgenesis khususnya transfer gen antivirus pada udang windu telah berhasil dilakukan melalui teknik transfeksi. Meskipun demikian optimalisasi komponen teknologi tersebut masih perlu dilakukan. Konsentrasi DNA gen merupakan salah satu komponen teknologi transgenesis yang harus dioptimalkan untuk mendapatkan efisiensi dalam transfer gen. Penelitian bertujuan untuk mengetahui konsentrasi DNA gen antivirus yang optimal sebagai bahan transfer gen ke embrio menggunakan metode transfeksi. Embrio udang windu yang diperoleh dari hasil pemijahan induk asal Aceh, dikoleksi 5-10 menit setelah memijah dengan kepadatan 625 telur/ $2 \mathrm{~mL}$. Transfeksi dilakukan dengan menggunakan media larutan transfeksi jetPEl dengan konsentrasi DNA gen antivirus sebagai perlakuan, yakni: 5, 10, dan $15 \mu \mathrm{g}$ serta kontrol positif (tanpa plasmid DNA) dan negatif (tanpa plasmid DNA dan larutan transfeksi), masing- masing 3 ulangan. Embrio hasil transfeksi ditetaskan pada stoples berisi air laut sebanyak 2 L yang diletakkan pada waterbath. Hasil penelitian menunjukkan bahwa gen antivirus telah berhasil diintroduksi ke embrio udang windu. Hasil analisis ragam menunjukkan bahwa perbedaan konsentrasi DNA (5- $15 \mu \mathrm{g}$ ) tidak berpengaruh nyata $(P>0,05)$ terhadap daya tetas embrio udang windu. Analisis ekspresi gen pada larva udang windu juga menunjukkan adanya aktivitas ekspresi gen antivirus pada semua perlakuan konsentrasi DNA, di mana ekspresi gen antivirus pada larva transgenik lebih tinggi dibandingkan dengan kontrol (tanpa transfeksi). Sintasan pasca- larva PL- 1 yang didapatkan pada penelitian ini adalah $12,0 \% 10,0 \% 10,6 \% 12,3 \%$ dan $14,2 \%$ masing- masing untuk perlakuan konsentrasi plasmid DNA $5 \mu \mathrm{g}, 10 \mu \mathrm{g}, 15 \mu \mathrm{g}$, kontrol positif dan negatif, di mana konsentrasi DNA yang berbeda tidak memperlihatkan pengaruh nyata $(P>0,05)$ terhadap sintasan larva PL- 1 . Hasil penelitian ini berimplikasi bahwa untuk alasan efisiensi, konsentrasi DNA $5 \mu \mathrm{g}$ disarankan untuk digunakan dalam transfer gen pada embrio udang windu.
\end{abstract}

KATA KUNCl: transfer gen, gen antivirus, udang windu, konsentrasi DNA

ABSTRACT: Transfer of antiviral gene with different DNA concentrations to tiger shrimp Penaeus monodon embryo. By: Andi Parenrengi, Andi Tenriulo, Syarifuddin Tonnek, and Samuel Lante

Transgenic technology, particularly the genetic manipulation to produce diseaseresistant tiger shrimp is a potential strategy to overcome disease problems in tiger shrimp culture. Technology of transgenic such as transfer of antiviral gene was 
preliminarily successful on tiger shrimp. However, the optimization on the technology components is needed to be undertaken. The concentration of DNA is one of the important parameters that determines the efficiency of a transgenic proccess. The experiment was aimed to determine the optimal DNA concentration of antiviral gene as the material in gene transfer procedure to tiger shrimp embryo through transfection method. Tiger shrimp embryos produced from Aceh broodstocks were collected 5-10 mins after spawning with density of 625 eggs $/ 2 \mathrm{~mL}$. Gene transfer was conducted by using transfection reagent jetPEI with different DNA concentrations as the treatments which were $15 \mu \mathrm{g}, 10 \mu \mathrm{g}, 5 \mathrm{\mu g}$, positive control (without DNA plasmid) and negative control (without DNA plasmid and transfection reagent) with three replicates. Transfected embryos were hatched in plactic cans filled with $2 L$ of seawater and placed in a water bath container. The results of the experiment showed that the antiviral gene has been successfully transferred to the tiger shrimp embryos. Variance analysis showed that different concentrations of DNA plasmid did not significantly affect $(P>0.05)$ the hatching rate of the embryos. Analysis of transient expression of larvae showed that the expression activity was observed among the treatments, where the transgenic larva showed higher expression compared with the control shrimp. Survival rates of post-larva PL-1 obtained in this experiment were $12.0 \%$, $10.0 \%, 10.6 \%, 12.3 \%$, and $14.2 \%$ for DNA concentration of $5 \mu \mathrm{g}, 10 \mu \mathrm{g}, 15 \mathrm{ug}$, positive and negative control, respectively. Different concentration of DNA did not significantly affect $(P>0.05)$ the survival rate of post-larvae PL-1. Based on these results, it is recommended that $5 \mu \mathrm{g} D N A$ is the optimal concentration of DNA to be used in gene transfer on tiger shrimp embryo.

\section{KEYWORDS: gene transfer, antiviral gene, tiger shrimp, DNA concentration}

\section{PENDAHULUAN}

Udang windu Penaeus monodon merupakan salah satu spesies lokal (indigenous species) krustase Indonesia. Budidaya udang windu sudah berkembang di tambak- tambak air payau dan telah menghasilkan devisa negara yang cukup signifikan. Meskipun demikian, sejak tahun 1990- an, budidaya udang windu mengalami berbagai kendala, baik akibat lingkungan perairan yang kurang mendukung maupun adanya serangan penyakit bakteri maupun virus. Kasus ini tidak hanya terjadi di Indonesia (Atmomarsono, 2004), tetapi juga terjadi di negara lain seperti India (Sathish et al., 2004; Rout et al., 2005), Korea (Kim et al., 2004), China (Zhan et al., 2004), dan Amerika (Galavis- Silva et al., 2004; Guevara \& Meyer, 2006). Sedikitnya 20 jenis virus penyebab penyakit pada budi daya udang telah dilaporkan (Zhang et al., 2004). Virus bintik putih merupakan jenis virus penyebab utama berbagai kasus kematian udang windu atau dikenal sebagai penyakit white spot syndrome virus (WSSV) yang hingga kini belum dapat diatasi secara tuntas.

Berbagai upaya penanggulangan penyakit pada budidaya udang windu telah dilakukan, tetapi belum memperlihatkan hasil yang optimal. Sebuah metode baru yang dikenal dengan istilah transgenesis diharapkan dapat mengatasi kelemahan metode sebelumnya. Teknologi transgenesis adalah suatu proses mengintroduksikan satu atau lebih DNA asing ke hewan uji dengan tujuan untuk memanipulasi fenotipnya ke arah yang lebih baik dan selanjutnya dapat ditransmisikan ke keturunannya (Beaumont \& Hoare, 2003). Transgenesis merupakan teknik modern yang berpotensi besar dalam upaya menghasilkan organisme yang memiliki karakter lebih baik melalui DNA rekombinan gen target, yang berguna bagi akuakultur seperti peningkatan laju pertumbuhan, perbaikan kualitas daging, peningkatan daya tahan baik terhadap lingkungan ekstrim maupun terhadap penyakit.

Penerapan teknologi transgenesis dalam peningkatan resistensi ikan/ udang terhadap serangan penyakit atau patogen merupakan salah satu alternatif pemecahan masalah penyakit pada akuakultur. Pada spesies krustase, khususnya pada udang, peningkatan resistensi melalui teknologi transgenesis masih terbatas. Penemuan gen pengkode antimikroba penaeidin membuka peluang dalam peningkatan imunitas udang melawan serangan patogen. Aplikasi penaeidin telah memperlihatkan efek peningkatan resistensi pada udang Litopenaeus vannamei (Destoumieux et al., 1997). Induksi imun pada 
udang melalui vaksinasi telah dilaporkan dengan penggunaan rekombinan protein WSSV pada udang $P$. chinensis (Kim et al., 2004), antivirus menggunakan untai ganda RNA (double-stranded RNA, dsRNA) pada udang L. vannamei (Robalino et al., 2004). Teknologi transfer gen hemocyanin pengkode antimikroba pada udang windu baru dimulai oleh Zhang et al. (2004). Selanjutnya transfer gen antivirus melalui introduksi gen penyandi TSV- CP (taura syndrome virus-coat protein) ke dalam embrio udang L. vannamei telah dilaporkan oleh Sun et al. (2005) dan Lu \& Sun (2005). Penelitian tersebut membuktikan bahwa introduksi gen pengontrol antivirus dapat meningkatan resistensi udang vaname terhadap serangan penyakit TSV.

Berdasarkan uraian tersebut, penanggulangan penyakit WSSV pada udang windu memungkinkan dilakukan melalui transfer gen pengkode antivirus. Promoter dan gen antivirus dapat diisolasi dari udang windu khususnya udang yang lolos (survivor) dari serangan penyakit WSSV (Luo et al., 2003; 2007). Keberhasilan transfeksi gen antivirus pada udang windu akan memberikan manfaat dalam upaya peningkatan sintasan udang windu yang dibudidayakan, yang akhirnya produksi udang windu dapat meningkat. Hasil dari penelitian diharapkan dapat memberikan dampak dalam peningkatan produksi perikanan akuakultur Indonesia, khususnya produksi udang windu di tambak. Keberhasilan isolasi, karakterisasi, kloning promoter/gen antivirus, dan pembuatan konstruksi gen (Parenrengi et al., 2009a: 2009b), serta transfer gen antivirus pada embrio udang windu (Parenrengi, 2010) merupakan langkah awal dalam upaya produksi udang windu tahan penyakit. Optimasi parameter utama dalam pengembangan teknik transfer gen khususnya metode transfeksi menggunakan larutan jetPEl sangatlah penting dilakukan untuk mendapatkan teknik yang efisien. Konsentrasi DNA plasmid merupakan salah satu parameter yang berperan dalam efisiensi transfer gen ke embrio udang windu. Oleh karena itu, penentuan konsentrasi DNA plasmid yang optimal untuk diaplikasikan pada transfer gen antivirus pada embrio udang windu merupakan upaya yang harus dilakukan dalam perakitan komponen teknologi transfer gen antivirus untuk menghasilkan udang tahan penyakit. Penelitian ini bertujuan untuk mendapatkan konsentrasi plasmid DNA yang efisien untuk diaplikasikan pada transfer gen antivirus pada embrio udang windu.

\section{BAHAN DAN METODE}

\section{Pematangan dan Pemijahan Induk}

Induk udang windu yang berasal dari Aceh diadaptasikan di bak karantina untuk keperluan deteksi bebas penyakit atau SPF (specific pathogen free) khususnya WSSV dan IHHNV. Induk SPF selanjutnya dipelihara dalam bak beton berukuran $3 \mathrm{~m}^{3}$ sistem air mengalir dengan kepadatan 10 ekor dengan rasio jantan:betina adalah 1:1. Pakan induk berupa cumi-cumi dan cacing laut diberikan 2 kali sehari yakni pagi dan sore hari sebanyak 15\% dari bobot badan. Untuk mempercepat pematangan gonad dilakukan ablasi mata, yaitu dengan memotong tangkai bola mata induk udang. Dalam waktu 3-4 hari setelah ablasi, induk udang menunjukkan kematangan gonad. Udang yang telah matang gonad (TKG-IV) dipindahkan ke bak pemijahan yang berbentuk kerucut dengan volume $200 \mathrm{~L}$ yang didesain khusus dengan pembuatan lubang di kedua sisi bak dan dilengkapi dengan lampu pijar 5 watt untuk memudahkan pemantauan waktu pemijahan terjadi. Pemijahan pada umumnya terjadi pada malam hari. Sekitar 5-10 menit setelah pemijahan dilakukan koleksi telur untuk keperluan transfeksi.

\section{Transfer Gen Antivirus ke Embrio}

Isolasi plamid DNA dari konstruksi gen ProAV- PmAV pada bakteri rekombinan dilakukan dengan menggunakan kit Plasmid DNA Isolatian (Vivantis) mengikuti prosedur manualnya. Keberhasilan isolasi plasmid dilakukan melalui deteksi keberadaan promoter dan gen antivirus pada DNA plasmid melalui teknik PCR dan pengukuran konsentrasi plasmid dilakukan pada spektrofotometer UV- VIS. Prosedur transfeksi gen antivirus PmAV ke dalam telur udang windu mengacu pada manual larutan tranfeksi jetPEl yang telah dikembangkan oleh Parenrengi (2010). Segera setelah pemijahan, telur yang terbuahi dikoleksi dan dibuat konsentrat untuk mendapatkan jumlah telur yang banyak. Konsentrat telur $2 \mathrm{~mL}$ ditransfer dalam cawan petri ( $35 \mathrm{~mm} \times 10 \mathrm{~mm}$ ). Sementara itu, plasmid DNA pada berbagai konsentrasi sebagai perlakuan yakni $5 \mu \mathrm{g}, 10 \mu \mathrm{g}$, dan 15 $\mu \mathrm{g}$ dicampurkan dengan $8 \mu \mathrm{L}$ larutan jetPEI $(7,8$ $\mathrm{mM}$ ) yang masing- masing telah dicampurkan dengan larutan $\mathrm{NaCl} 150$ mM. Sebanyak 200 $\mu \mathrm{L}$ campuran plasmid DNA dan larutan transfeksi dimasukkan ke dalam konsentrat 
telur yang sudah disiapkan dalam cawan petri. Sebagai kontrol perlakuan dilakukan juga transfeksi pada embrio tanpa menggunakan plasmid DNA (kontrol positif) dan tanpa menggunakan plasmid DNA dan larutan transfeksi (kontrol negatif). Campuran tersebut selanjutnya diinkubasi pada suhu ruangan selama 50 menit sebelum dipindahkan ke dalam stoples 2,5 L yang diisi dengan air laut steril dan dilengkapi dengan aerasi untuk proses penetasan. Untuk mengurangi fluaktuasi suhu, stoples-stoples diletakkan dalam wadah/bak (waterbath) yang telah dilengkapi dengan pemanas (heater). Setelah penetasan sekitar 24- 36 jam, naupli yang dihasilkan dihitung untuk mendapatkan daya tetas embrio dan pengambilan sampel naupli sebanyak 50 individu (pooled sample) untuk keperluan analsis genom DNA dan cDNA untuk ekspresi gen antivirus. Naupli yang berhasil menetas selanjutnya dipelihara sampai dengan PL- 1 untuk melihat pengaruh perlakuan terhadap sintasan pasca- larva udang windu.

\section{Analisis DNA Genom dan Ekspresi Gen Antivirus}

DNA genom dan RNA yang dilanjutkan dengan sintesis CDNA (complementary-DNA) diekstraksi dari 50 naupli (pooled sample) untuk uji konfirmasi masuknya gen antivirus PmAV pada embrio dan larva udang windu. Ekstraksi DNA genom menggunakan metode fenol-kloroform yang telah dikembangkan pada ikan kerapu (Parenrengi et al., 2000), sedangkan isolasi RNA dilanjutkan dengan sintesis cDNA menggunakan kit Ready-To-Go You-Pime First Strand Beads (GE Healthcare). Analisis ekspresi gen antivirus PmAV dilakukan dengan menggunakan teknik RT-PCR. Gen antivirus dan ekspresinya dideteksi dengan teknik semi kuantitatif PCR, di mana sampel telur tanpa transfeksi digunakan sebagai kontrol dalam penelitian ini. Primer yang digunakan adalah ORF PmAV- F 5'- tag tgc atg cat atg ggt cat aca atc cta- $3^{\prime}$ dan ORFPmAV- $\mathrm{R}$ $5^{\prime}$ - ctg tct cga gct atg tgt cct gct ttc aca3', dengan menggunakan DNA genom dan CDNA sebagai templat PCR. Proses amplifikasi dijalankan pada mesin PCR GenAmp AB- 7200 (Applied Biosystem) dengan program predenaturasi $94^{\circ} \mathrm{C}$ selama 3 menit; 35 siklus untuk denaturasi $94^{\circ} \mathrm{C}$ selama 30 detik, annealing $58^{\circ} \mathrm{C}$ selama 30 detik, dan ekstensi $72^{\circ} \mathrm{C}$ selama 45 detik; serta final ekstensi $72^{\circ} \mathrm{C}$ selama 3 menit. Ekspresi gen $\beta$ - aktin udang windu digunakan sebagai kontrol internal seperti yang telah dikembangkan oleh Sriphaijit \& Senapin (2007). Untuk melihat keberhasilan amplifikasi fragmen DNA target, hasil PCR dielektroforesis pada gel agarose 2\%pada tegangan 50 Volt selama 1- 2 jam dan didokumentasi dengan Gel Documentation System (Biometra). Untuk menentukan berat molekul fragmen DNA digunakan marker VC 100bp Plus DNA Ladder (Vivantis).

\section{Analisis Data}

Derajat penetasan embrio/telur dan sintasan pasca- larva PL- 1 dihitung berdasarkan jumlah telur yang menetas menjadi naupli dan larva PL- 1 dibandingkan dengan jumlah telur yang diinkubasi. Untuk mengetahui pengaruh konsentrasi DNA plasmid terhadap derajat penetasan dan sintasan PL- 1 dilakukan analisis ragam dengan menggunakan program Statistix Versi 3.0 (NH Analytical Software) dan dilanjutkan dengan uji beda nyata terkecil pada taraf $5 \%$ Uji konfirmasi masuknya gen antivirus dilakukan dengan teknik PCR dan ekspresi sementaranya dianalisis melalui teknik RT- PCR dimana data yang dihasilkan disajikan secara deskriptif.

\section{HASIL DAN BAHASAN}

\section{Daya Tetas Embrio dan Sintasan Pasca- Larva PL- 1}

Daya tetas embrio udang windu yang dihasilkan pada penelitian ini memperlihatkan persentase sekitar 20,3\% 29,0\%(Tabel 1). Hasil analisis ragam menunjukkan bahwa perbedaan konsentrasi plasmid DNA yang diintroduksi tidak mempengaruhi $(\mathrm{P}>0.05)$ daya tetas embrio udang windu. Hasil pemantauan terhadap efek konsentrasi plasmid DNA yang digunakan telah dilakukan sampai dengan fase pasca- larva PL- 1. Sintasan PL- 1 udang windu antara perlakuan transfeksi dengan konsentrasi 5- $15 \mu$ g sekitar 10,0\% 12,0\%relatif sama dengan kontrol positif dan negatif masing- masing adalah $12,3 \%$ dan $14,2 \%$ (Gambar 1). Hasil analisis ragam menunjukkan bahwa perbedaan konsentrasi plasmid DNA tidak berpengaruh signifikan $(P>0,05)$ terhadap sintasan larva PL- 1. Hal tersebut menunjukkan bahwa penggunaan konsentrasi DNA sampai dengan $15 \mu \mathrm{g}$ belum membahayakan bagi perkembangan embrio dan sintasan larva PL1 , demikian halnya dengan penggunaan larutan jetPEl pada konsentrasi $8 \mu \mathrm{L}$ juga tidak 
Tabel 1. Daya tetas embrio dan deteksi genom udang windu P. monodon hasil transfeksi konstruksi gen antivirus pada berbagai konsentrasi DNA

Table 1. Hatching rate of embryo and genome DNA detection of tiger shrimp P. monodon transfected by antiviral gene construct with different DNA concentrations

\begin{tabular}{ccc}
$\begin{array}{c}\text { Konsentrasi plasmid DNA } \\
\text { DNA plasmid } \\
\text { concentration }\end{array}$ & $\begin{array}{c}\text { Daya tetas } \\
\text { Hatching rate } \\
\text { (\%) }\end{array}$ & $\begin{array}{c}\text { Deteksi genom DNA pada naupli } \\
\text { Genome DNA detection of } \\
\text { larva } \boldsymbol{e}^{*}\end{array}$ \\
\hline $15 \mu \mathrm{g}$ & $21.7 \pm 5.03^{\mathrm{a}}$ & + \\
$10 \mu \mathrm{g}$ & $20.3 \pm 3.21^{\mathrm{a}}$ & + \\
$5 \mu \mathrm{g}$ & $22.3 \pm 3.51^{\mathrm{a}}$ & + \\
Kontrol positif & $28.0 \pm 5.29^{\mathrm{a}}$ & - \\
$\begin{array}{c}\text { Positive control } \\
\text { Kontrol negatif }\end{array}$ & $29.0 \pm 6.93^{\mathrm{a}}$ & - \\
Negative control & & \\
\hline
\end{tabular}

Keterangan (Notes):

Angka pada kolom yang sama dan diikuti oleh huruf yang sama menunjukkan tidak berbeda nyata $(\mathrm{P}>0,05)$, angka ditulis dalam rataan $\left.\pm \mathrm{SD} ;{ }^{*}\right)=$ analisis dilakukan terhadap 50 naupli (pooled sample), di mana gen antivirus positif (+) atau negatif (- ) terdeteksi pada genom DNA

The values in same column followed by the same superscript are not statistically significantly different $(P>0.05)$, number in average $\pm S D ;{ }^{*}=$ analysis performed by 50 larvae (pooled sample), where the antiviral gene positively $(+)$ and negatively (-) detected on the DNA genome

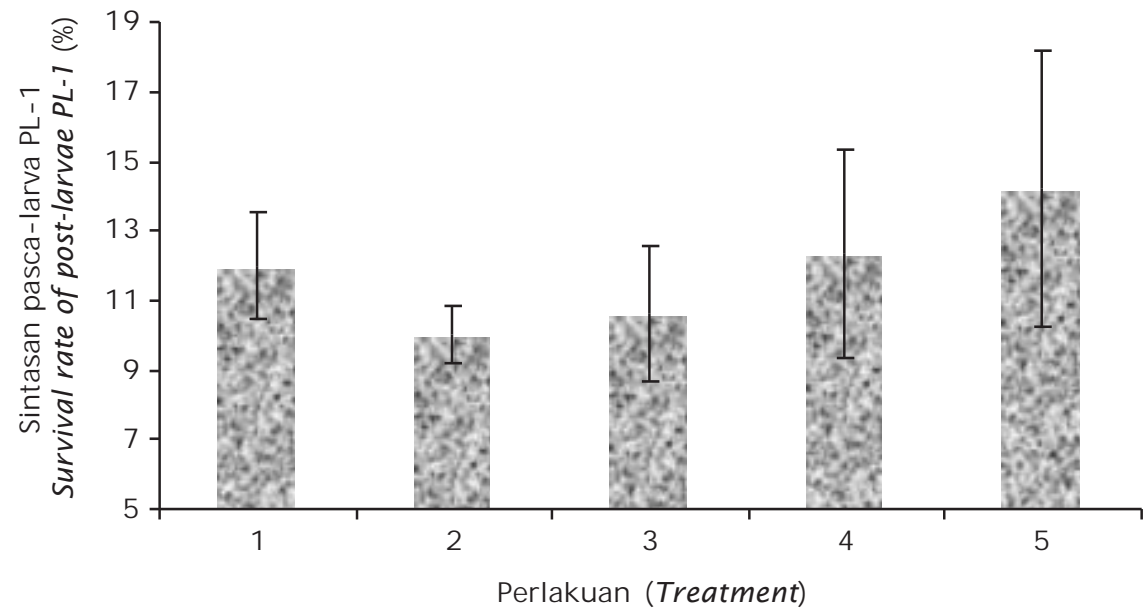

Gambar 1. Sintasan pasca- larva PL- 1 hasil transfeksi gen antivirus berbagai konsentrasi DNA (Perlakuan $1=5 \mu \mathrm{g} ; 2=10 \mu \mathrm{g} ; 3=15 \mu \mathrm{g} ; 4$ = kontrol positif; dan $5=$ kontrol negatif, serta garis bar $=\mathrm{SD}$ )

Figure 1. Survival rate of post-larvae PL-1 transfected with antiviral gene at different DNA concentrations (Treatment $1=5 \mu \mathrm{g} ; 2=10 \mu \mathrm{g} ; 3=\mu \mathrm{g}$; $4=$ positive control, and $5=$ negative control, bar line $=S D$ )

membahayakan bagi embrio udang windu dengan melihat indikator daya tetas perlakuan kontrol positif yang diberi larutan jetPEI tetapi tanpa plasmid DNA. Hasil penelitian tersebut berimplikasi bahwa penggunaan larutan jetPEI sebagai media transfer gen antivirus tidak memberikan efek berbahaya bagi perkembangan embrio udang windu. Pembuktian 
tersebut dilakukan dari hasil pengamatan daya tetas embrio udang windu pada perlakuan transfeksi dengan menggunakan kontrol positif (tanpa konstruksi gen) dan kontrol negatif (tanpa larutan tranfeksi dan konstruksi gen), di mana derajat penetasan embrio antara perlakuan tersebut tidak memperlihatkan perbedaan yang nyata $(P>0,05)$. Toksisitas larutan tersebut juga dilaporkan sangat rendah (Horbinski et al., 2001) dan mudah mengalami degredasi secara alami (Ahn et al., 2002). Hal ini menunjukkan bahwa dosis jetPEI dan DNA yang digunakan tidak mempengaruhi daya tetas embrio udang windu. Hasil tersebut memberikan peluang besar dalam pengembangan teknologi transgenesis pada udang dengan menggunakan metode larutan transfeksi karena tidak membahayakan embrio udang windu. Pada penelitian ini digunakan plasmid yang mengandung konstruksi gen proAV- PmAV yang diisolasi dari udang windu (Parenrengi, 2010). Beberapa studi menunjukkan bahwa plasmid konstruksi gen tidak memberikan pengaruh negatif pada sintasan embrio setelah transfeksi. Introduksi konstruksi gen (promoter dan gen $\beta$ galaktosidase) melalui teknik elektroporasi kepada embrio ikan zebra tidak memberikan dampak negatif yang ditandai dengan daya tetas $72 \%$ dibandingkan dengan kontrol yakni 85\%(Sheela et al., 1998). Di lain pihak, dengan jetPEl, vektor ekspresi p $\beta$ actP2- TSV- CP dapat ditransfer ke embrio udang vaname dengan laju transfer yang tinggi, baik sebelum terbentuknya lapisan jeli pada bagian luar telur $(72 \%$ ) maupun setelah jeli terbentuk (50\%) (Sun et al., 2005). Daya tetas yang relatif rendah $(17,6 \% 20,1 \%)$ pada embrio udang windu dilaporkan oleh Yasawa et al. (2005) dengan menggunakan metode mikroinjeksi konstruksi gen $P J E F-G F P$.

Rendahnya daya tetas tersebut diperkirakan karena inkubasi dilakukan pada wadah stoples (volume air $2 \mathrm{~L}$ dengan kepadatan telur yang relatif tinggi yakni 625 telur/stoples). Selain itu, daya tetas embrio yang rendah tersebut diduga akibat kualitas telur yang digunakan relatif rendah. Hal tersebut dibuktikan dengan rendahnya pula daya tetas embrio pada perlakuan kontrol negatif. Seperti halnya dengan penelitian sebelumnya bahwa penetasan embrio udang windu hasil transfeksi dan kontrol mencapai daya tetas $38,1 \%$ 43,1\% dengan kepadatan 370 telur/ stoples (Parenrengi, 2010). Dari jumlah telur dan daya tetas yang digunakan, metode transfeksi memiliki potensi yang besar untuk diaplikasikan dalam transfer gen pada udang. Yasawa et al. (2005) melaporkan bahwa transfer gen pada udang menggunakan metode particle gun bombardment dapat dilakukan dalam jumlah telur yang relatif lebih banyak yakni 8.300-13.480 telur dengan daya tetas sekitar $29,8 \% 60,3 \%$ sedangkan dengan metode mikroinjeksi hanya sekitar sekitar 204580 telur dengan daya tetas yang relatif rendah $(17,6 \% 20,1 \%$.

Pemilihan metode transfeksi pada penelitian ini didasarkan atas pertimbangan bahwa ukuran telur udang windu sangat kecil dan perkembangan sel embrio relatif cepat. Dengan metode tersebut, jumlah telur yang dapat diaplikasikan relatif lebih besar, tergantung kemampuan dan keahlian dalam penyediaan telur dalam jumlah yang banyak tetapi dalam waktu yang singkat. Pada penelitian ini, telur udang windu dapat dipadatkan sampai dengan konsentrasi 625 embrio/ $2 \mathrm{~mL}$ air laut. Keberhasilan produksi udang transgenik dipengaruhi oleh metode transfer gen yang dipilih. Metode transfer gen akan berpengaruh terhadap waktu dan biaya yang digunakan serta laju integrasi gen ke genom inang. Beberapa metode transfer gen yang dikembangkan pada mamalia telah diaplikasikan pada ikan. Metode yang umum digunakan untuk memproduksi ikan transgenik adalah mikroinjeksi. Meskipun demikian, elektroporasi, mediasi lewat sperma, particle gun bombardment, dan transfeksi juga telah memperlihatkan efektivitasnya dalam transfer DNA ke genom ikan (Khoo, 2000). Metode mikroinjeksi telah terbukti efektif dalam teknologi transgenesis pada ikan dengan mempertimbangkan ukuran telur yang relatif besar. Berbeda halnya dengan transgenesis pada krustase khususnya pada udang, beberapa peneliti telah mengkaji aplikasi beberapa metode transfer gen pada udang. Studi penggunaan tiga metode transfer gen yakni mikroinjeksi, elektroporasi, dan transfeksi gen pada udang vaname telah dilakukan oleh Sun et al. (2005). Hasil penelitian tersebut menunjukkan bahwa transfeksi memperlihatkan metode yang paling sesuai pada udang vaname berdasarkan alasan ukuran telur yang relatif kecil, daya tetas yang tinggi, serta dapat diaplikasikan dalam jumlah yang banyak. Dengan metode transfeksi menggunakan larutan jetPEl, daya tetas telur udang dapat mencapai 50\% 60\% jauh lebih besar dibandingkan dengan metode 
mikroinjeksi (3- 5\%) dan elektroporasi (25\% 35\%). Demikian halnya dengan jumlah telur yang bisa diberi perlakuan adalah mencapai 50.000 telur untuk metode transfeksi, sedangkan metode elektroporasi hanya mencapai 15.000 telur dan mikroinjeksi 50 telur. Berdasarkan pertimbangan tersebut, metode transfer gen yang dapat dikembangkan pada embrio udang windu adalah metode transfeksi menggunakan Iarutan jetPEI. Berdasarkan pengamatan perkembangan sel pada embrio udang windu, formasi terbentuknya dua sel mulai terlihat pada pengamatan 60 menit setelah pemijahan, pada suhu $27^{\circ} \mathrm{C}-29^{\circ} \mathrm{C}$. Oleh karena itu, pelaksanaan transfeksi sebaiknya dilakukan sebelum terbentuknya dua sel atau sebelum 60 menit setelah pemijahan. Hal yang relatif sama disarankan juga pada udang vaname, dimana pembentukan dua sel pada embrio mulai terjadi 55 menit setelah pemijahan sehingga transfeksi gen sebaiknya dilakukan sebelum waktu tersebut atau lebih baik lagi jika dilakukan sebelum terbentuknya lapisan jeli pada permukaan telur vaname yang terjadi 13 menit setelah pemijahan (Sun et al., 2005).

\section{Deteksi DNA Genom dan Ekspresi Gen Antivirus}

Uji konfirmasi keberadaan gen antivirus pada embrio udang windu dilakukan dengan menggunakan DNA genom sebagai cetakan PCR. Hasil analisis PCR menunjukkan bahwa embrio udang windu yang ditransfeksi telah positif membawa gen antivirus dalam tubuhnya dengan indikasi keberadaan fragmen DNA pada posisi sekitar 520 bp, yang tidak didapatkan pada embrio udang yang tidak ditransfeksi konstruksi gen antivirus, kontrol positif dan negatif (Tabel 1 dan Gambar 2A). Keberhasilan masuknya gen target ke embrio udang melalui metode transfeksi menggunakan larutan jetPEl juga telah dilaporkan oleh peneliti sebelumnya. Meskipun demikian, beberapa larutan transfeksi dapat digunakan sebagai media introduksi vektor ekspresi ke dalam embrio udang, misalnya Effectene dan Superfect dari Qiagen, serta Lipofectamine 2000 dari GibcoBRL. Sun et al. (2005) melaporkan bahwa metode transfeksi menggunakan jetPEl pada udang vaname menunjukkan laju efisiensi transfer gen mencapai $40 \% 60 \%$, sedangkan dengan metode mikroinjeksi dan elektroporasi masingmasing adalah $10 \%$ 20\%dan $10 \%$ 15\%

Metode RT- PCR semi- kuantitatif dilakukan untuk mengetahui tingkat ekspresi sementara (transient gene expression) gen antivirus pada berbagai konsentrasi plasmid DNA. Elektroforesis hasil analisis RT- PCR terhadap ekspresi sementara gen antivirus pada berbagai konsentrasi plasmid disajikan pada Gambar 2B, dengan menggunakan kontrol internal dari ekspresi gen $\beta$ - aktin udang windu (Gambar 2C).
K
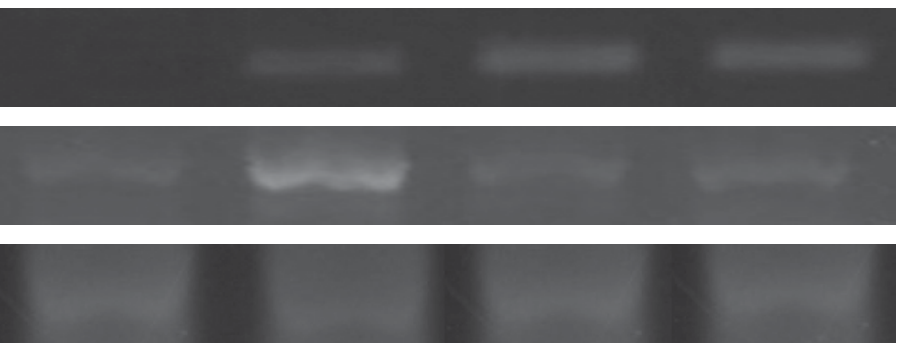

A

B

C

Gambar 2. Analisis genom DNA dan ekspresi gen antivirus larva udang windu pada berbagai konsentrasi DNA. A = larva udang windu positif membawa gen antivirus; $\mathrm{B}=$ ekspresi gen antivirus; $\mathrm{C}=$ kontrol internal ekspresi gen $\beta$ - aktin udang windu, dimana konsentrasi DNA plasmid $5 \mu \mathrm{g}(1)$; $10 \mu \mathrm{g}(2)$; $15 \mu \mathrm{g}(3)$; dan kontrol (K)

Figure 2. Analysis of DNA genome and gene antiviral expression on tiger shrimp larvae transfected with different DNA concentrations. A = tiger shrimp positively carrying antiviral gene; $B=$ expression of antiviral gene; $C=$ internal control of $\beta$-actin gene expression of tiger shrimp, where plasmid DNA concentration of $5 \mu \mathrm{g}(1) ; 10 \mu \mathrm{g}$ (2); $15 \mu \mathrm{g}$ (3); and control (K) 
Hasil analisis DNA genom pada naupli udang windu menunjukkan adanya gen antivirus yang positif terdapat pada semua perlakuan transfeksi baik pada konsentrasi 5 $\mu \mathrm{g}$ mapun pada konsentrasi 10 dan $15 \mu \mathrm{g}$ (Tabel 1 dan Gambar 2). Walaupun pengambilan sampel dilakukan secara gabungan individu (pooled sample) dari berapa ekor naupli, tetapi Gambar 2 telah memperlihatkan keberadaan fragmen DNA pada posisi yang sama dengan gen antivirus (target) dibandingkan dengan kontrol udang tanpa transfeksi. Meskipun pada perlakuan $5 \mu \mathrm{g}$ memperlihatkan ekspresi relatif lebih tinggi, tetapi secara umum tidak berbeda signifikan dengan perlakuan lainnya. Hal ini diduga disebabkan karena penggunaan konsentrasi yang berbeda tidak diiringi dengan peningkatan konsentrasi larutan jetPEI dan $\mathrm{NaCl}$ (larutan garam), sehingga efektivitas pengikatan DNA plasmid oleh larutan garam dan larutan transfeksi pada konsentrasi $10 \mu \mathrm{g}$ dan $15 \mu \mathrm{g}$ lebih rendah dibandingkan dengan konsentrasi $5 \mu \mathrm{g}$. Keberhasilan tersebut membuktikan bahwa larutan transfeksi jetPEI dapat digunakan sebagai media introduksi gen asing ke embrio udang windu. Hasil yang sama juga dilaporkan oleh Parenrengi et al. (2010) bahwa penggunaan larutan transfeksi jetPEl telah digunakan untuk memasukkan gen berpendar EGFP (enhanced green fluorescent protein). Penggunaan larutan tersebut tidak terbatas pada udang windu, Sun et al. (2005) juga telah berhasil melakukan transfer gen ke embrio udang vaname, L. vannamei, bahkan dengan penggunaan konsentrasi DNA yang lebih rendah sekitar $1 \mu \mathrm{g}$ yang dicampur dengan 1,2 $\mu \mathrm{L}$ larutan jetPEl dalam $2 \mathrm{~mL}$ air laut steril. Hasil penelitian tersebut juga melaporkan bahwa penggunaan metode transfeksi dapat dilakukan dengan menggunakan embrio yang lebih banyak yakni dapat mencapai 20.000-50.000 embrio, di mana jauh lebih tinggi dibandingkan metode elektroporasi (10.000-15.000 embrio) dan mikroinjeksi (20- 50 embrio). Sedangkan pada analisis ekspresi transgen (Gambar 2) pada larva udang windu juga menunjukkan adanya aktivitas ekspresi gen yang ditandai dengan adanya fragmen DNA pada posisi yang ditargetkan. Hasil penelitian tersebut memperlihatkan bahwa dengan transfeksi gen antivirus, ekspresi gen relatif lebih tinggi dibandingkan dengan kontrol (tanpa transfeksi). Berdasarkan uraian tersebut, untuk tujuan efisiensi penggunaan $5 \mu \mathrm{g}$ DNA plasmid sebagai bahan untuk transfer gen antivirus pada embrio udang windu sudah cukup memadai untuk digunakan. Seperti halnya dengan rekomendasi penggunaan Iarutan jetPEl dalam manual yang dikeluarkan adalah sekitar $6 \mu \mathrm{g}$ untuk transfer gen ke sel pada umumnya.

\section{KESIMPULAN DAN SARAN}

Transfer gen antivirus menggunakan metode transfeksi dapat dilakukan sebagai media/ larutan transfer gen ke embrio udang windu. Penggunaan konsentrasi DNA plasmid DNA yang mengandung konstruksi gen antivirus dari 5- $15 \mu \mathrm{g}$ tidak mempengaruhi daya tetas embrio bahkan tidak berdampak negatif pada sintasan pasca- larva PL- 1 udang windu. Hasil penelitian tersebut, berimplikasi bahwa untuk alasan efesiensi, konsentrasi DNA 5 ug disarankan untuk digunakan dalam transfer gen pada embrio udang windu. Untuk mengetahui secara kuantitatif ekspresi gen antivirus, maka disarankan untuk menggunakan anailsis menggunakan real-time PCR.

\section{DAFTAR ACUAN}

Ahn, C.H., Chae, S.Y., Bae, Y.H., \& Kim, S.W. 2002. Biodegradable poly(ethylenimine) for plasmid DNA delivery [abstract]. J. Contr. Rel., 80:273- 282.

Atmomarsono, M. 2004. Pengelolaan kesehatan udang windu, Penaeus monodon di tambak. Akua. Indonesiana, 5: 73- 78.

Beaumont, A.R. \& Hoare K. 2003. Biotechnology and genetics in fisheries and Aquaculture. Blackwell Science, $158 \mathrm{pp}$.

Destoumieux, D., Bulet, P., Loew, D., Dorsselaer, A.V., Rodriguez, J., \& Bachere, E. 1997. Penaeidins, a new family of antimicrobial peptide isolated from the shrimp Penaeus vannmaei (Decapoda). J. Biol. Chem., 272(45): 28398- 28496.

Galaviz- Silva, L., Molina- Graza, Z.J., AlcocorGonzalez, J.M., Rosales- Encinas, J.L., \& Ibarra-Gamez, C. 2004. White spot syndrome virus variants detected in Mexico by a new multiplex PCR method. Aquaculture, 242: 53- 68.

Guevara, L.I.P. \& Meyer, M.L. 2006. Detailed monitoring of white spot syndrome virus (WSSV) in shrimp commercial ponds in Sinaloa, Mexico by nested PCR. Aquaculture, 251: 33- 45. 
Horbinski, C., Stachowiak, M.K., Higgins, D., \& Finnegan, S.G. 2001. Polythyleneiminemediated transfection of cultured postmitotic neurons from rat sympathetic ganglia and adult human retina. BMC Neurosci, 2: 1471- 2202.

Khoo, H.W. 2000. Transgenesis and its applications in aquaculture. Asian Fish Sci., 8: 1-25.

Kim, D.K., Jang, I.K., Seo, H.C., Shin, S.O., Yang, S.Y., \& Kim, J.W. 2004. Shrimp protected from WSSV disease by treatment with egg yolk antibodies (IgY) against a truncated fusion protein derivated from WSSV. Aquaculture, 237: 21- 30.

Lu, Y. \& Sun, P.S. 2005. Viral resistant in shrimp that express an antisense Taura syndrome virus coat protein gene. Antivir Res, 67: 141- 146.

Luo, T., Zhang, X., Shao, Z., \& Xu, X. 2003. PmAV, a novel gene involved in virus resistance of shrimp Penaeus monodon. FEBS Lett, 551: 53- 57.

Luo, T., Fang, L., Kaiyu, L., \& Xu, X. 2007. Genomic organization, promoter characterization, and expression profiles of an antiviral gene PmAV from the shrimp Penaeus monodon. Mol Immunol, 44: 1516- 1523.

Parenrengi, A., Shamsudin, L., Ismail, P., \&Amin, N.M. 2000. Preliminary study on DNA level marker of grouper at different buffer preservation and DNA extraction method. In Saad MS, Faridah QZ, Kadir MA., Khalid MZZ, Mohamad O, Saleh GB, Panandam JM (Editors). Genetic Manipulation: Challenges and Advantages. Proceeding of the $4^{\text {th }}$ National Congress on Genetics, 26- 28 Sept.2000, Genting Highlands, Malaysia, p. 194- 208.

Parenrengi, A., Alimuddin, Sukenda, Sumantadinata, K., Yamin, M., \&Tenriulo, A. 2009a. Cloning of ProAV promoter isolated from tiger prawn Penaeus monodon. Indonesian Aqua J., 4: 1- 7.

Parenrengi, A., Alimuddin, Sukenda, Sumantadinata, K., \& Tenriulo, A. 2009b. Karakteristik Sekuens cDNA Pengkode Gen Antivirus dari Udang Windu, Penaeus monodon. J. Ris. Akuakultur, 4: 1- 13.

Parenrengi, A., Alimuddin, Sukenda, Sumantadinata, K., \&Tenriulo, A. 2010. Uji aktivitas promoter antivirus pada udang windu penaeus monodon menggunakan gen egfp sebagai penanda. Makalah dipresentasikan pada Forum Inovasi Teknologi Akuakultur (FITA) di Lampung, 18 hlm.

Robalino, J., Browdy, C.L., Prior, S., Metz, A., Parnell, P., Gross, P., \&Warr, G. 2004. Induction of antiviral immunity by doublestranded RNA in a marine invertebrata. $J$. Virol, 78: 10442- 10448.

Rout, N., Citarasu, T., Ravindran, R., \& Murugan, V. 2005. Transcriptional and translation expression profile of a white spot syndrome viral (WSSV) gene in different organs of infected shrimp. Aquaculture, 245: 3138.

Sathish, S., Selvakkumar, C., Hameed, A.S.S., \& Narayanan, R.B. 2004. 18- kd protein as a marker to detect WSSV infection in shrimps. Aquaculture, 238: 39- 50.

Sheela, S.G., Chen, J.D., Mathavan, S., \& Pandian, T.J. 1998. Construction, electroporatic transfer and expression of Zp $\beta y p G H$ and ZpßrtGH in zebrafish. J Biosci, 23: 565- 576.

Sriphaijit, T. \& Senapin, S. 2007. High expression of a novel leucine- rich repeat protein in hemocyte and lymphoid organ of the black tiger shrimp Penaeus monodon. Fish \& Shellfish Immunol, 22: 264- 271.

Sun, P.S., Venzon, N.C., Calderon, F.R.O., \& Esaki, D.M. 2005. Evaluation of methods for DNA delivery into shrimp zygotes of Penaeus (Litopenaeus) vannamei. Aquaculture, 243: 19-26.

Yasawa, R., Watanabe, K., Koyama, T., Ruangapan, L., Tassanakajon, A., Hirono, I., \& Aoki, T. 2005. Development of gene transfer technology for black tiger shrimp, Penaeus monodon. J. Exp Zoo, 303: 11041109.

Zhan, W., Wang, X., Chen, J., Xing, J., \& Fukuda, $H$. 2004. Elimination of shrimp endogenous alkaline phosphatase immunoassays for the detection of white spot syndrome virus (WSSV). Aquaculture, 239: 15- 21.

Zhang, X., Huang, C., \& Qin, Q. 2004. Antiviral properties of haemocyanin isolated from shrimp Penaeus monodon. Antivir Res., 61: 93-99. 